offered to-day upon both these matters; but being comn pelled by the exigencies of the life I lead to deal with these matters in a practical spirit-in other words, to calculate the length, the breadth, and the weight of the obstacles which have to be encountered-the remedy is not quite so easy to discover and to apply as to the more sanguine among us it may, at first sight, appear. For instance, there is this question of raising the age of exemption. There you are confronted with these discouraging figures from the Lancashire operatives, where, upon a poll on the question of raising the half-time age to thirteen, barely 34,000 voted in the affirmative and no less than 150,000 voted in the negative. I agree that a few years ago the figures would have been much more discouraging than they are now. But one hopes that with the advance of information and the efforts of the enlightened leaders like my friend $\mathrm{Mr}$. Shackleton there may be a considerable movement in a better direction. But it is obvious that at the moment it would be extremely difficult to apply by any statutory form of compulsion a measure which, so far as regards the great bulk of the operatives are concerned, a large majority are not prepared voluntarily and spontaneously to accept. That is a case for what is called spade-work, which I hope may produce its results before long. When we come to the question of continuation schools, I think the prospect is more satisfactory and hopeful. We did something for Scottish education in the Scottish Act last year, and I hope it is not too sanguine a view to take if one expresses the hope that England will soon level itself up to the standard of Scotland in that matter. Again there is a difficulty. As one of the speakers pointed out, if the boys or the girls are kept hard at work in a monotonous way at unintellectual occupations during a great many hours of the day, you cannot expect them to bring to the continuation school, or evening school, anything like a fresh intelligence or that power of receptivity which is essential to the efficient working of such institutions. There comes in that question of the half-timer again. I cannot help thinking that if employers of labour would more generally take the course which Sir Alber Spicer has taken, and which Mr. Cadbury has taken, of making it a condition when they employ these young boys and girls in their works that they should spend one or two evenings in a continuation school, their regular hours of labour being so adjusted that it is not an excessive strain either upon their intellectual or physical capacity, we should find, if not a solution, the way of going very near to the solution of that part of the problem.

A report upon the problem of education in relation to apprenticeship, especially as it concerns the children of London, is to be presented by the Higher Education Sub-committee of the London County Council Education Committee at a meeting to be held as we go to press. In this report the committee urges that, inasmuch as industrial training is a national and not a local question, technical institutions and technical scholarships should be supported to a much larger extent than at present out of funds provided by the National Exchequer.

As remedies for what are pronounced defects in our educational methods, leading to waste of effort and the sacrifice of future prospects to immediate needs, the committee makes a number of proposals which are identical in principle with suggestions for an organised educational system contained in the report of the British Science Guild Education Committee already published in these columns. The proposals put forward by the London County Council Committee may be summarised as follows :-

(I) The age of compulsory attendance at elementary schools should be raised to fifteen.

(2) Certain children should be transferred at the age of thirteen to trade or craft schools.

(3) The elementary-school curriculum should be made more practical by a considerable increase in the time devoted to various kinds of manual training.

(4) Local education authorities should be empowered to compel employers to allow their apprentices and learners the necessary time during the day to attend classes, and to entorce such attendance on the apprentices and learners. (5) At least half the working day should be spent in school.

(6) All boys and girls not on the rolls of trade or secondary schools should be required to pass through a three years" course of "half-time" instruction at continuation schools.

It is to be hoped that statesmen will not wait until a mandate is received from those who benefit by child-labour before attempting to make our educational demands comparable with those of Scotland and Germany. Their duty is to safeguard the mental and physical welfare of the coming generation if our nation is to be kept in the van of progress. The continuation of the present system involves grave injustice to a not inconsiderable part of the child population of England, for the mental, moral, and physical training received during school life is soon lost after a boy drifts into one of the occupations of unslilled trades. As to further education, whether in day or evening continuation schools, or in secondary schools, there is much to be done before we can approach the conditions existing in Germany. While Germany is fast extending the age of compulsory attendance through the critical years of youth, in England and Wales not more than one in three of the children who leave the public elementary schools at thirteen or fourteen years of age receives any further systematic care as regards education of any kind. When our statesmen realise what a study in contrasts is afforded by the German and English systems of education, and what an inferior position we occupy, judged by any standard of educational measurement, they will perhaps do something to prevent the waste of body and mind which is a source of individual poverty and of national weakness.

\section{SIR GEORGE KING, K.C.I.E., F.R.S.}

SIR GEORGE KING, K.C.I.E., F.R.S., whose death at San Remo was announced in NATURE of February 18, was born at Peterhead on April I2, 1840. He was educated at the Grammar School and the University, Aberdeen, graduating in medicine in 1865. In the same year he entered the Indian Medical Service, and was posted to the Bengal Presidency.

Soon after reaching India, King was detailed for military medical duty in Central India and Rajputana, where his leisure was devoted to work of high quality as a field naturalist. From military duty he was transferred to act temporarily as superintendent of the Botanic Gardens at Saharanpur, in Upper India; shortly thereafter he was induced to join the Indian Forest Service, and was placed in charge of the Kumaon forests. While so employed he was selected by the Secretary of State for India as successor to Dr. Thomas Anderson, whose death in October, I87o, had left vacant the superintendentship of the Royal Botanic Gardens at Calcutta and of Cinchona Cultivation in Bengal.

When, in 1871 , King assumed charge of the Calcutta gardens these were in the ruined condition to which they had been reduced by severe cyclones in I864 and again in I867. They had practically to be renovated, and the charm and beauty for which they are famed constitute an adequate memorial to King's energy, patience, and skill as a landscape gardener. The prolonged task involved considerable expenditure, and the readiness with which the necessary funds were supplied bears witness to the traditional enlightenment of the Government of Bengal and to

No. 2052, VOL. 79] 
the confidence which King's organising powers inspired.

The cinchona department was just passing beyond the experimental stage when King was given control. Natural causes render the cultivation of cinchona in northern India unprofitable to private enterprise. Notwithstanding this fact, King so administered the Government plantations and factory that the Government was able, without incurring pecuniary loss, to place the remedies against malaria which cinchona bark yields within the reach of the poorest peasant in India.

The extent and gravity of King's administrative duties did not prevent him from prosecuting the botanical studies which made him one of the leading systematic botanists of the last quarter of the nineteenth century; but with rare self-denial he forbore the publication of his results until the tasks of restoring the gardens and organising the plantations and factory under his charge had progressed so far as to justify his giving the time that was needed to the preparation of ordered statements. But the fact that his scientific attainments were on a level with his administrative powers could not remain concealed from those with whom he corresponded on botanical subjects, and in 1884 he was promoted to the degree of LL.D. by his own university, while in 1887 he was elected into the Royal Society.

In the last-mentioned year the enlightened policy of the Government of Bengal enabled King to found the "Annals" of the Calcutta gardens, a series of sumptuous volumes in which he proceeded to enrich systematic study by providing monographs of difficult and important genera like Ficus, Quercus, Castanopsis, Artocarpus, Myristica, and families like Magnoliaceæ, Anonaceæ, and Orchidaceæ. These contributions to natural knowledge are characterised by the accuracy, lucidity, and completeness which marked everything he did. But as regards the branch of botany of which he thus became so distinguished an exponent, King was influenced by the sense of duty that had so long delayed the publication of his results. His personal predilections were towards problems other than systematic, and, as might be expected in one who had been a favourite pupil of the late Prof. Dickie, F.R.S., these were problems associated with cryptogamic studies. But King's practical mind realised that, important and enticing as such studies are, the path of duty for him led elsewhere. The greatest immediate service he could render to the official and commercial interests of India lay in the provision of recognisable descriptions of hitherto unknown or imperfectly understood phanerogamic plants of economic importance, and especially, as his experience as a forest official had taught him, recognisable descriptions of trees, too frequently neglected by workers whose study of herbaceous plants and shrubs may leave nothing to be desired. To this task King devoted himself in the most single-minded fashion, and in furthering it he commenced in 1889 the publication of the results of a sustained floristic study of the vegetation of the Malayan peninsula, issued from time to time in fascicles that were professedly intended to serve as precursors to a flora of that region, but are so admirably executed that they serve as an efficient substitute for such a work. In $189 \mathrm{I}$, when the various botanical officers in India were linked together in one department, King became the first director of the Botanical Survey of India.

During his Indian career King was able to render much additional service to the country and its Government. He was long a trusted member of the Senate, and served for a term on the syndicate of the
University of Calcutta. He was a member of the board of visitors of the Bengal Engineering College, an institution in which he took a warm and effective interest. $\mathrm{He}$ was an original member of the committee of management of the Zoological Gardens at Calcutta, the site of which he found occupied by a collection of hovels, and converted into a singularly attractive place of public resort. $\mathrm{He}$ was for many years a trustee of the Indian Museum, and for a time was chairman of the trust. He was president of the central committee appointed by Government to investigate the indigenous drugs of India, from its inception in 1894 until his retirement in 1898 after thirty-three years of devoted service to the people and the Government of India.

After his retirement King gave all his energies to the continuation of his "Materials for a Flora of the Malayan P'eninsula.' But his health, severely tried by his long residence in the East, became gradually more and more impaired, and he realised that he might never see the completion of the work he had allotted himself. His friend Mr. H. N. Ridley, F.R.S., director of the Botanic Gardens, Singapore, stepped into the breach and undertook the elaboration of the monocotyledonous families while King was engaged on the remainder of the dicotyledonous ones, and after I902, when the thirteenth fasciculus, completing the Calycifioræ, was issued, another friend, Mr. J. S. Gamble, F.R.S., became associated with him in working out the Corollifloræ. Increasing infirmity gradually led to King taking less and less of an active share in the work, and the later families have been elaborated by Mr. Gamble alone.

King's skill as a landscape gardener led to the award of its Victoria medal by the Royal Horticultural Society. His services to humanity in connection with the manufacture and distribution of the alkaloids of cinchona bark were recognised by honorary membership of the Pharmaceutical Society, by the grade of "Officier d'Instruction publique," and by the gift of a ring of honour by H.I.M. Alexander III. of Russia. His invaluable contributions to natural knowledge brought him honorary association with a number of learned societies, and the award of medals by the University of Upsala and the Linnean Society of London, while his administrative qualities were recognised, on the eve of his retirement, by the Government of India.

King was keenly interested in art, in literature, and in many branches of science other than that in the promotion of which he took so active a part. With wide and accurate knowledge he combined a kindly sense of humour and a magnetic charm of manner which rendered intercourse with him a privilege never to be forgotten, and to his many friends his death leaves a blank that cannot be filled.

\section{NOTES.}

AT the meeting of the Royal Society on Thursday, February 18, telegrams of congratulation on the hundredth anniversary of the birth of Charles Darwin were read from the University of Christiania, the University, Kharkoff, the Naturalists' Students' Association, Kharkoff, the Society of Naturalists, Kharkoff, the council of lecturers, Moscow Women's University, and the Swedish Academy of Sciences, Stockholm. The president reported that telegraphic acknowledgments and thanks had been transmitted to the senders on behalf of the Royal Society.

M. H. Poincaré has been elected president of the French Bureau des Longitudes; M. Bigourdan becomes vice-president, and M. Deslandres secretary.

$$
\text { NO. 2052, VOL. 79] }
$$

